\title{
Two cell-wall-associated aminopeptidases from Lactobacillus helveticus and the purification and characterization of APII from strain ITGL1
}

\author{
Brigitte Blanc,* Patrick Laloi, Danièle Atlan, Christophe Gilbert and \\ RAYMOND PORTALIER
}

Laboratoire de Microbiologie et Génétique Moléculaire, Centre de Génétique Cellulaire et Moléculaire (CNRS UMR 106), Université Claude Bernard-Lyon I, Bâtiment 405, 43 bd du 11 novembre 1918, 69622 Villeurbanne cédex, France

(Received 25 November 1992; revised 11 February 1993; accepted 26 March 1993)

\begin{abstract}
Lactobacillus helveticus ITGL1 is able to hydrolyse many amino-acyl and dipeptidyl-p-nitroanilides. Analysis of heat inactivation kinetics, metal ion and protease inhibitor effects, and the subcellular location of aminopeptidase activities in both the parental strain and mutants deficient in lysyl-p-nitroanilide hydrolysis, led to the characterization of two cell-wall-associated aminopeptidases, APII and APIV. APII, which catalysed L-lysine pnitroanilide hydrolysis, was purified about 28-fold to homogeneity from cell-wall extracts of $L$. helveticus ITGL1 and characterized. The purified enzyme appeared to be monomeric, with a molecular mass of $97 \mathrm{kDa}$. Aminopeptidase activity was greatest at $\mathrm{pH} 6.5$ and $50^{\circ} \mathrm{C}$. APII was completely inhibited by bestatin, chelating agents such as EDTA or 1,10-phenanthroline and the divalent cations $\mathrm{Zn}^{2+}$ and $\mathrm{Cu}^{2+}$. The activity of the EDTAtreated enzyme was restored by $\mathrm{Co}^{2+}, \mathrm{Ca}^{2+}$ or $\mathrm{Mn}^{2+}$. Although APII was able to degrade several dipeptides and tripeptides with hydrophobic N-terminal amino acid (Leu, Ala), it was inactive on peptides containing Pro or Gly, and may thus contribute to the development of cheese flavour by processing bitter peptides.
\end{abstract}

\section{Introduction}

Lactic acid bacteria play important roles in food production and preservation, especially in the dairy industry. These bacteria are unable to synthesize most amino acids and require an exogenous nitrogen source for growth (Thomas \& Pritchard, 1987, Law \& Koshlstad, 1983). The concentrations of free amino acids in milk are not sufficient to support significant cell growth. Therefore, lactococci depend on proteolytic systems that consist of several proteinases and aminopeptidases to degrade milk caseins into assimilable peptides and free amino acids (Kok, 1990; Laan et al., 1989). The cell-wall-bound proteinases of lactic acid bacteria perform the first steps in the hydrolysis of casein (Kok, 1990; Kok \& Venema, 1988). Subsequent steps in casein catabolism are catalysed by peptidases, and make possible the degradation into smaller products of relatively large peptide fragments released by the proteinases (Monnet et al., 1986, 1989). An understanding of the

*Author for correspondence. Tel. 337244 8105; fax 3372431181.

Abbreviations: pNA, para-nitroanilide, AP, aminopeptidase, DPAP, dipeptidyl aminopeptidase. roles played by peptidases in casein degradation requires the isolation and biochemical characterization of purified enzymes (for review see Kok, 1990).

The use of lactobacilli such as Lactobacillus helveticus together with streptococci has been shown to shorten the time of cheese ripening and thus reduce costs (Bartels et al., 1987). This has been associated with an increase in the level of some amino acids and peptides that give the fermentation products their characteristic organoleptic properties. The present investigation was undertaken to analyse the proteolytic system of $L$. helveticus.

$L$. helveticus is able to hydrolyse $\alpha_{\mathrm{s}}$ and $\beta$-caseins; it contains high levels of general aminopeptidase (AP), proline imminopeptidase (Pro-IP) and aminopeptidase-P activities, but no carboxypeptidase activity (Hickey et al., 1983). A prolyl-dipeptidyl aminopeptidase (Khalid \& Marth, 1990a) and an intracellular aminopeptidase (Khalid \& Marth, 1990b) have been purified from $L$. helveticus CNRZ 32, and characterized. Another aminopeptidase has been purified from $L$. helveticus LHE-511 (Miyakawa et al., 1992).

In the present study, we have developed a procedure for the release of cell wall proteins from $L$. helveticus ITGL1 (industrial strain). Heat inactivation studies and differential inhibition by EDTA and metal ions indicated 
the existence of two aminopeptidases, which we named APII and APIV. We also report the analysis of mutants deficient in APII and the purification and the properties of cell-wall-associated APII.

\section{Methods}

Organism and culture conditions. Lactobacillus helveticus ITGL1 was supplied by the Institut Technique du Gruyère, La Roche sur Foron, France. L. helveticus was grown at $40^{\circ} \mathrm{C}$ without shaking in $125 \mathrm{ml}$ flasks containing $100 \mathrm{ml}$ culture medium. Rich peptide medium was MRS broth (Difco; De Man et al., 1960). Reconstituted 10\% (w/v) skim milk solutions from skim milk powder (Elle et Vire, Union Laitière Normande, Condé-sur-Vire, France) were centrifuged $\left(15000 \mathrm{~g}, 15 \mathrm{~min}, 6^{\circ} \mathrm{C}\right)$ and then autoclaved at $110^{\circ} \mathrm{C}$ for $15 \mathrm{~min}$. When MRS medium was used, $\beta$-galactosidase synthesis was induced by adding $1 \mathrm{mM}$-IPTG.

Subcellular fractionation. (i) Total cellular extracts. Total cellular extracts were obtained as previously described (Atlan et al., 1989). (ii) Cell wall and cytoplasmic extracts. Proteins were extracted from the bacterial cell wall of $L$. helveticus using a modification of the procedure previously developed to release APII from Lactobacillus delbrueckii subsp. bulgaricus (Atlan et al., 1989). After 4 h growth in $100 \mathrm{ml}$ MRS or milk medium $\left(A_{600}=0 \cdot 8-1 \cdot 0\right)$, cells were harvested by centrifugation $\left(10000 \mathrm{~g}, 10 \mathrm{~min}, 6^{\circ} \mathrm{C}\right)$, washed in $25 \mathrm{mM}-\mathrm{KH}_{2} \mathrm{PO}_{4}, 10 \mathrm{~mm}-\mathrm{MgCl}_{2}$ (pH 5.8) and resuspended in $10 \mathrm{ml}$ of the same buffer supplemented with $0.6 \mathrm{M}$-sucrose and treated with 0.1 or $1 \mathrm{mg} \mathrm{m}^{-1}$ (for cells grown in MRS or milk medium, respectively) of lysozyme from chicken egg white (Sigma) for $30 \mathrm{~min}$ at 25 or $37^{\circ} \mathrm{C}$ (for cells grown in MRS or milk medium, respectively) with gentle shaking. Bacterial suspensions were centrifuged $\left(10000 \mathrm{~g}, 10 \mathrm{~min}, 6^{\circ} \mathrm{C}\right)$ and the supernatants are referred to as lysozyme fluids. Lysozyme-treated bacteria were osmotically shocked by suspending them in $10 \mathrm{ml}$ cold distilled water and maintained on ice for $10 \mathrm{~min}$. Shocked cells were centrifuged $(10000 \mathrm{~g}$, $10 \mathrm{~min}, 6^{\circ} \mathrm{C}$ ) and these supernatants are referred to as osmotic fluids. The bacterial pellets were resuspended in $10 \mathrm{ml}$ cold distilled water and disrupted with a French pressure cell (20000 p.s.i. [138 MPa], $6{ }^{\circ} \mathrm{C}$; Amicon). The supernatants obtained after centrifugation of the broken cells $\left(25000 \mathrm{~g}, 20 \mathrm{~min}, 6^{\circ} \mathrm{C}\right)$ are referred to as soluble cytoplasmic fluids.

Enzyme assays. AP activities were assayed as previously described (Atlan et al., 1989) with lysyl- (3 mM), arginyl- (10 mM) or leucyl-pnitroanilide (pNa) $(15 \mathrm{~mm})$ as substrates. Alanyl-proline-pNA (6 mM) was used as the substrate for assaying pro-dipeptidyl aminopeptidase activity (Pro-DPAP). One unit (U) of AP or Pro-DPAP activity was defined as the amount of enzyme that hydrolysed $1 \mu \mathrm{mol}$ substrate $\min ^{-1}$.

Caseinolytic activity was determined as previously described (Atlan et al., 1990). $\beta$-Galactosidase activity was assayed with $o$-nitrophenyl$\beta$-D-galactopyranoside ( $3 \mathrm{mM}$ ) as the substrate (Miller, 1972). One unit of enzyme activity was defined as the amount of enzyme that hydrolysed 1 nmol substrate $\min ^{-1}$.

Hydrolysis of various peptides was detected by TLC. APII activity was assayed as follows. The reaction mixture, containing $2 \mathrm{~mm}$ substrate in $20 \mathrm{~mm}$-HEPES ( $\mathrm{pH} \mathrm{7.0)}$ ), and an appropriate amount of enzyme, was incubated for $60 \mathrm{~min}$ at $40^{\circ} \mathrm{C}$. The reaction mixture $(10 \mu \mathrm{l})$ was then spotted onto a precoated silica gel 60 plate with a gel layer thickness of $0 \cdot 25 \mathrm{~cm}$ (Merck). A 4:1:1 (by vol.) mixture of nbutanol/acetic acid/water was used as the mobile phase. As a control, $2 \mathrm{~mm}$ of each standard peptide and amino acid were also spotted onto the plate. Silica gels were stained by spraying them with $0.1 \%$ ninhydrin in ethanol. Peptides and amino acids became visible after the silica gel was incubated for $5 \mathrm{~min}$ at $80^{\circ} \mathrm{C}$.
Electrophoretic analysis. SDS-PAGE was done by the method of Laemmli (1970). Polyacrylamide gel gradients $(7-15 \%$, w/v) were routinely used. Before electrophoresis, samples were boiled for $3 \mathrm{~min}$ in $0 \cdot 1 \mathrm{M}-\beta$-mercaptoethanol in the presence of $1 \%(\mathrm{w} / \mathrm{v})$ SDS. Electrophoresis continued for $13 \mathrm{~h}$ at a constant $16 \mathrm{~mA}$. After migration, gels were stained at $50{ }^{\circ} \mathrm{C}$ with $0.1 \%$ Coomassie brilliant blue in methanol/acetic acid/water (50:10:40, by vol.) and then diffusion destained for $12 \mathrm{~h}$ at $30^{\circ} \mathrm{C}$ in successive baths of methanol/acetic acid/water ( $5: 10: 85$, by vol.).

The purified APII fraction was analysed by PAGE in $7 \%(\mathrm{w} / \mathrm{v})$ acrylamide gel without SDS. Migration was in 100 mM-HEPES buffer, $\mathrm{pH} 7.4$, at $12^{\circ} \mathrm{C}$. Enzyme activity was detected directly on the gel by incubation in the following mixture: $10 \mathrm{mg} \mathrm{Arg}-\beta$-naphthylamide in $1 \mathrm{ml}$ dimethylformamide and $50 \mathrm{mg}$ Fast Garnet GBC (Sigma) in $30 \mathrm{ml}$ $50 \mathrm{mM}-\mathrm{H}_{2} \mathrm{NaPO}_{4} / \mathrm{HNa}_{2} \mathrm{PO}_{4}$ buffer, $\mathrm{pH} 7 \cdot 0$. Hydrolysis of the substrate was correlated with the appearance of a red colour at the level of the enzyme.

Purification of aminopeptidase $I I$. Osmotic fluids $(100 \mathrm{ml})$ were prepared from L. helveticus ITGL1 grown in milk medium using the procedure described above $\left(1 \mathrm{mg}\right.$ lysozyme $\mathrm{ml}^{-1}$ for $30 \mathrm{~min}$ at $37^{\circ} \mathrm{C}$ ) and were lyophilized. Freeze-dried extracts were resuspended in $10 \mathrm{ml}$ $20 \mathrm{~mm}$-Tris/ $\mathrm{HCl}, \mathrm{pH} 7 \cdot 5$. The following purification steps were carried out at $4{ }^{\circ} \mathrm{C}$. (i) First ion-exchange chromatography. The concentrated extract was applied to a column of Mono-Q HR 5/5 (Pharmacia) equilibrated with $20 \mathrm{~mm}$-Tris $/ \mathrm{HCl}, 7 \cdot 5$. A linear gradient of $\mathrm{NaCl}$ $(0-0.5 \mathrm{M})$ in the same buffer was run over $10 \mathrm{~min}$ at a flow rate of $1 \mathrm{ml} \mathrm{min}{ }^{-1}$ and $0.5 \mathrm{ml}$ fractions were collected. Fractions hydrolysing lysyl-pNA with the highest activity were pooled and concentrated with an Amicon filtration unit using a XM-10 membrane (molecular mass cutoff $10 \mathrm{kDa}$; Amicon).

(ii) Gel filtration chromatography. The concentrated active extract was applied to a column of Superose 12 HR 10/30 (Pharmacia) and

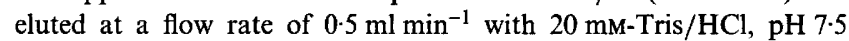
containing $40 \mathrm{~mm}-\mathrm{NaCl}$. Fractions with the highest lysyl-AP activity were pooled and concentrated by filtration on a XM10 membrane in $20 \mathrm{~mm}$-Tris/HCl buffer, $\mathrm{pH} 7.5$. The molecular mass of the active enzyme was estimated in these conditions, and the column was calibrated using Sigma standards : cytochrome $c(12 \cdot 4 \mathrm{kDa})$, carbonic anhydrase $(29 \mathrm{kDa})$, BSA $(66 \mathrm{kDa})$, alcohol dehydrogenase $(150 \mathrm{kDa})$ and $\beta$-amylase $(200 \mathrm{kDa})$.

(iii) Second ion-exchange chromatography. The second ion-exchange chromatography was done as described for the first step, but with a linear $\mathrm{NaCl}$ gradient of $0 \cdot 15-0.28 \mathrm{M}$ in $26 \mathrm{~min}$ at a flow rate of $0.5 \mathrm{ml} \mathrm{min}^{-1}$.

Heat treatment. Enzyme extracts were treated at $62^{\circ} \mathrm{C}$ as previously described (Atlan et al., 1989).

Isoelectric focusing. Isoelectric focusing in polyacrylamide gels was done as previously described (Laloi et al., 1991) with ampholine $\mathrm{pH} \mathrm{4-6}$ (LKB), $40 \mathrm{~mm}$-glutamate as anolyte and $0.2 \mathrm{M}$-histidine as catholyte. The following proteins were used as $\mathrm{pI}$ markers: carbonic anhydrase A from human erythrocytes (Sigma, pI 6.57), carbonic anhydrase B from bovine erythrocytes (Boehringer, pI 5.85), $\beta$-lactoglobulin A from bovine milk (Sigma, pI 5.20) and trypsin inhibitor from soybean (Sigma, pI 4.55).

Protein determination. The protein content of enzyme preparations was determined by the method of Bradford (1976), using BSA as the standard.

Effect of divalent cations and chemical reagents on APII activity. The purified enzyme was preincubated in the presence or absence of various ions or inhibitors for $30 \mathrm{~min}$ at $4{ }^{\circ} \mathrm{C}$. After addition of the substrate (lysyl-pNA), enzyme activity was determined at $50^{\circ} \mathrm{C}$ in 20 mM-MES, 
Table 1. Enzymic analysis of parental strain and AP-deficient mutants of L. helveticus

Total extracts were prepared from cells grown for $4 \mathrm{~h}$ in MRS or milk medium. Data are means of three independent cultures.

\begin{tabular}{|c|c|c|c|c|c|c|}
\hline \multirow{2}{*}{$\begin{array}{l}\text { Growth medium } \\
\text { and strain }\end{array}$} & \multicolumn{6}{|c|}{ Enzyme activity [ $\left.\mathrm{U}(\mathrm{mg} \text { bacterial dry } \mathrm{wt})^{-1}\right]$} \\
\hline & Lysyl-AP & Arginyl-AP & Leucyl-AP & X-Pro-DPAP & Caseinolytic & $\beta$-Galactosidase \\
\hline \multicolumn{7}{|l|}{ MRS medium } \\
\hline Parental strain ITGL1 & 24 & 22 & 12 & 30 & 1187 & 118 \\
\hline ITGL2 & 0.5 & $1 \cdot 1$ & $1 \cdot 6$ & 22 & 885 & 106 \\
\hline ITGL3 & 0.6 & $1 \cdot 7$ & $2 \cdot 3$ & 29 & 1163 & 100 \\
\hline \multicolumn{7}{|l|}{ Milk medium } \\
\hline Parental strain ITGL1 & 28 & 26 & 17 & 37 & 10996 & 83 \\
\hline ITGL2 & 0.5 & 0.5 & $2 \cdot 9$ & 35 & 8054 & 76 \\
\hline ITGL3 & $0 \cdot 25$ & $0 \cdot 4$ & $4 \cdot 1$ & 48 & 11086 & 94 \\
\hline
\end{tabular}

pH 6.5. EDTA- or 1,10-phenanthroline-treated enzyme was preincubated for $30 \mathrm{~min}$ at $4{ }^{\circ} \mathrm{C}$ with different ions in $20 \mathrm{~mm}$-MES, pH 6.5 before adding the substrate.

\section{Results and Discussion}

Proteolytic activities in parental and AP-deficient strains of L. helveticus

Total extracts from $L$. helveticus parental strain ITGL1, grown either in MRS or in milk medium, contained approximately equal amounts of peptidase activities responsible for the hydrolysis of lysyl-, arginyl-, leucylor alanyl-proline-pNA, (Table 1). However, the caseinolytic activity of strain ITGL1 grown in milk was ninefold higher than that of cells grown in MRS (Table 1). Similar results have been obtained with Lactobacillus delbrueckii subsp. bulgaricus, where the biosynthesis of the cell-surface proteinase depends on the nature of the culture medium (Laloi et al., 1991).

Mutant strains ITGL2 and ITGL3 were derived from $L$. helveticus ITGL1 by mutagenesis with nitrosoguanidine and identified on the basis of their inability to hydrolyse leucyl- $\beta$-naphthylamide (Prost \& Chamba, 1990 ) by using an in situ enzymic plate assay as described previously (Atlan et al., 1989). These mutants showed a marked decrease in leucyl-AP activity (Table 1) as well as lysyl- and arginyl-AP activities. Strain ITGL2 displayed caseinolytic and X-Pro-DPAP activities ranging from $75 \%$ to $100 \%$ of parental activities. We noted that X-Pro-DPAP activity of strain ITGL3 was slightly enhanced (1-3-fold) after growth in milk medium. $\beta$ Galactosidase activity, used as an independent marker of the proteolytic system, was not altered in the mutants (Table 1).
Subcellular location and characterization of two APs in L. helveticus

No lysyl-, arginyl- or leucyl-AP activity was detected in the culture medium during growth of $L$. helveticus ITGL1 (data not shown). Bacteria were treated with increasing concentrations of lysozyme, then osmotically shocked to release cell-wall-associated proteins. No significant AP activity was detected in the lysozyme fluids obtained from the first step, therefore we only analysed the effects of temperature, treatment time and lysozyme concentration on the release of AP activities into the osmotic fluid (second step) (Table 2).

When cells were grown in milk medium the optimal temperature $\left(37^{\circ} \mathrm{C}\right)$ and lysozyme treatment $\left(1 \mathrm{mg} \mathrm{ml}^{-1}\right.$ for $30 \mathrm{~min}$ ) induced the release of about $55 \%$ of the three AP activities (lysyl-, arginyl and leucyl-AP) into the osmotic fluid without significant cellular lysis $(<2.8 \%)$ as estimated by assaying $\beta$-galactosidase activity, a cytoplasmic marker, and X-pro-DPAP activity, which were all unreleased by lysozyme treatment in $L$. delbrueckii subsp. bulgaricus (Atlan et al., 1990). After growth in MRS medium, lysozyme concentration and treatment temperature were modified to minimize cellular fragility: in these conditions, $33 \%$ of the three AP activities were released during osmotic shock at $25^{\circ} \mathrm{C}$ in the presence of $0.1 \mathrm{mg}$ lysozyme $\mathrm{ml}^{-1}$.

The cellular location of leucyl-AP activity was analysed in the mutant strains ITGL2 and ITGL3 after growth in milk medium and treatment with $1 \mathrm{mg}$ lysozyme $\mathrm{ml}^{-1}$ for $30 \mathrm{~min}$ at $37^{\circ} \mathrm{C}$ (Table 3). High amounts of residual leucyl-AP activity ( 65 and $76 \%$ for ITGL2 and ITGL3, respectively) were released into osmotic fluids without significant cell lysis ( 1.8 and $4.5 \%$, respectively).

These results indicate that the enzymes responsible for lysyl-, arginyl- and leucyl-AP activities are localized in the cell wall. A similar method had previously allowed us 
Table 2. Effect of lysozyme concentration and temperature on the release of AP activities into osmotic fluids from L. helveticus parental strain grown in MRS or milk medium

\begin{tabular}{|c|c|c|c|c|c|c|c|c|c|c|c|}
\hline \multirow{2}{*}{\multicolumn{2}{|c|}{ Treatment }} & \multicolumn{10}{|c|}{ Release of enzyme activity $(\%)^{*}$} \\
\hline & & \multicolumn{2}{|c|}{$\beta$-Galactosidase } & \multicolumn{2}{|c|}{ Lysyl-AP } & \multicolumn{2}{|c|}{ Arginyl-AP } & \multicolumn{2}{|c|}{ Leucyl-AP } & \multicolumn{2}{|c|}{ X-Pro-DPAP } \\
\hline $\begin{array}{l}\text { Lysozyme } \\
(\mathrm{mg} / \mathrm{ml})\end{array}$ & $\begin{array}{l}\text { Temperature } \\
\left({ }^{\circ} \mathrm{C}\right)\end{array}$ & MRS & Milk & MRS & Milk & MRS & Milk & MRS & Milk & MRS & Milk \\
\hline 0.05 & 25 & 1.9 & - & $15 \cdot 1$ & - & 17 & - & $15 \cdot 6$ & - & $2 \cdot 9$ & - \\
\hline 0.08 & 25 & $1 \cdot 1$ & - & $19 \cdot 5$ & - & $21 \cdot 4$ & - & $20 \cdot 1$ & - & - & - \\
\hline $0 \cdot 1$ & 10 & 0.1 & - & 0.4 & - & $1 \cdot 1$ & - & 0 & - & - & - \\
\hline $0 \cdot 1$ & 25 & 3.6 & 0.4 & $30 \cdot 8$ & 0.8 & 33 & 1 & $34 \cdot 4$ & - & 4 & - \\
\hline $0 \cdot 1$ & 30 & $25 \cdot 6$ & - & $71 \cdot 9$ & - & $73 \cdot 2$ & - & $77 \cdot 2$ & - & $32 \cdot 3$ & - \\
\hline $0 \cdot 15$ & 25 & $14 \cdot 2$ & 0.4 & $55 \cdot 3$ & $2 \cdot 1$ & 58.4 & - & 61 & - & $27 \cdot 9$ & - \\
\hline $0 \cdot 25$ & 25 & $16 \cdot 6$ & 1 & $69 \cdot 1$ & $3 \cdot 4$ & - & - & - & - & - & - \\
\hline 0.4 & 25 & $21 \cdot 6$ & - & $77 \cdot 4$ & - & - & - & - & - & - & - \\
\hline $0 \cdot 6$ & 25 & - & $0 \cdot 2$ & - & 3 & - & - & - & - & - & - \\
\hline 1 & 25 & - & $0 \cdot 2$ & - & $4 \cdot 7$ & - & - & - & - & - & - \\
\hline 1 & 30 & - & $0 \cdot 3$ & - & 16 & - & $18 \cdot 4$ & - & - & _- & $1 \cdot 2$ \\
\hline 1 & 37 & - & 1 & - & 55 & - & $56 \cdot 5$ & - & 52 & - & $2 \cdot 8$ \\
\hline 2 & 25 & - & $0 \cdot 1$ & - & 6.5 & - & 7.8 & - & - & - & 0.9 \\
\hline
\end{tabular}

$* 100 \%$ Activity is defined as the sum of the activities measured in the three extracts (lysozyme, osmotic and cytoplasmic fluids).

,- Not determined.

Table 3. Distribution of leucyl-AP activity in different cellular extracts from peptidase deficient mutants of $L$. helveticus

Data are mean values from 3 independent cultures.

\begin{tabular}{|c|c|c|c|c|c|c|}
\hline \multirow{2}{*}{$\begin{array}{l}\text { Strain and cellular } \\
\text { fraction }\end{array}$} & \multicolumn{2}{|c|}{ Leucyl-AP } & \multicolumn{2}{|c|}{$\beta$-Galactosidase } & \multicolumn{2}{|c|}{ X-Pro-DPAP } \\
\hline & Activity* & $(\%)$ & Activity* & $(\%)$ & Activity* & $(\%)$ \\
\hline \multicolumn{7}{|l|}{ ITGL2 mutant } \\
\hline Lysozyme fluid & $0 \cdot 1$ & 4 & $0 \cdot 15$ & 0.2 & 0.2 & 0.6 \\
\hline Osmotic fluid & $1 \cdot 7$ & 65 & 0.45 & 0.6 & 0.6 & 1.8 \\
\hline Cytoplasmic fluid & 0.8 & 31 & $74 \cdot 3$ & $99 \cdot 2$ & $33 \cdot 1$ & 97.6 \\
\hline Total & $2 \cdot 6$ & 100 & $74 \cdot 9$ & 100 & $33 \cdot 9$ & 100 \\
\hline \multicolumn{7}{|l|}{ ITGL3 mutant } \\
\hline Lysozyme fluid & 0 & 0 & $0 \cdot 26$ & 0.3 & $0 \cdot 3$ & $0 \cdot 7$ \\
\hline Osmotic fluid & $2 \cdot 8$ & 76 & $1 \cdot 6$ & 1.8 & 1.9 & $4 \cdot 5$ \\
\hline Cytoplasmic fluid & 0.9 & 24 & $86 \cdot 5$ & 97.9 & $39 \cdot 9$ & 94.8 \\
\hline Total & $3 \cdot 7$ & 100 & $88 \cdot 4$ & 100 & $42 \cdot 1$ & 100 \\
\hline
\end{tabular}

*Activity is expressed in enzyme units (mg bacterial dry weight $)^{-1}$.

to differentially release APII, a specific enzyme responsible for lysyl-pNA hydrolysis, from Lactobacillus delbrueckii subsp. bulgaricus (Atlan et al., 1989). Treatment of osmotic fluids from L. helveticus parental cells grown in milk medium with the metal chelating agents EDTA ( $(0.1 \mathrm{mM})$ and 1,10-phenanthroline (1 mM) completely inhibited the lysyl- and arginyl-AP activities, but only $80 \%$ of the leucyl-AP activity. Moreover, residual leucyl-AP activity of osmotic fluids from mutant strains ITGL 2 and ITGL 3 was stimulated by $0.1 \mathrm{mm-EDTA.}$ Similar results were obtained for AP activities in osmotic fluids prepared from cells grown in MRS medium (data not shown). These results strongly suggest that at least two different enzymes are involved in leucyl-AP activity.

Osmotic fluids prepared from parental cells grown in MRS or milk medium were mixed and heat-inactivated at $62{ }^{\circ} \mathrm{C}$ to determine if the same enzyme(s) is (are) synthesized during growth in both culture media. Residual lysyl-, arginyl- and leucyl-AP activities were measured as a function of time. The logarithm of lysyland arginyl-AP activities decreased linearly with inactivation time to about $5 \%$ of the residual activities without a change in the slope and with a half-time of $7.5 \mathrm{~min}$ (Fig. 1). These results show that whatever culture medium was used, a single cell-wall-associated enzyme was responsible for the hydrolysis of lysyl- and arginyl-pNA. On the 


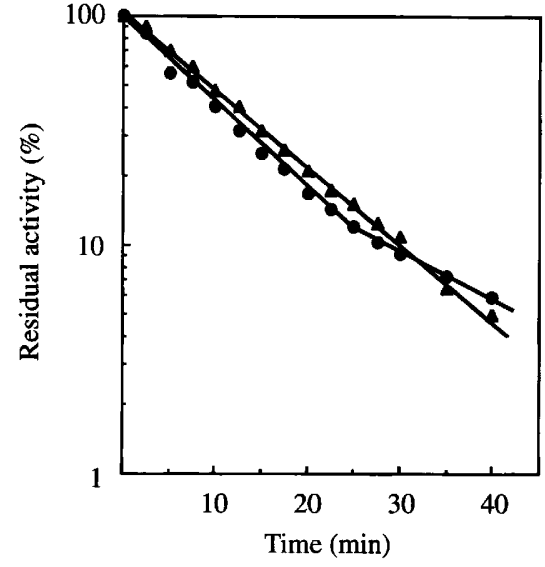

Fig. 1. Heat inactivation kinetics of lysyl- or arginyl- $(\mathbf{A})$ and leucyl-AP (๑) activities of $L$. helveticus ITGL1. Residual AP activities were estimated after heat treatment $\left(62^{\circ} \mathrm{C}\right)$ of a mixture $(1: 1, \mathrm{v} / \mathrm{v})$ of osmotic fluids prepared from parental strain ITGL1 grown either in MRS or milk medium.

other hand, the kinetics of heat inactivation at $62{ }^{\circ} \mathrm{C}$ of leucyl-AP activity were biphasic (Fig. 1), which suggests that at least two APs are involved in the leucyl-AP activity located in the $L$. helveticus cell wall.

Taken together, these data prompt us to propose that a single metal-containing enzyme is responsible for lysyland arginyl-AP activities as well as a part of the leucylAP activity. We named this enzyme APII, in agreement with the nomenclature proposed by Ezzat and coworkers (Ezzat et al., 1986). Moreover, a second AP contributes to leucyl-AP activity with properties similar to those of APIV from Lactobacillus delbrueckii subsp. bulgaricus (Atlan et al., 1989); we therefore propose the same name, APIV, for this AP of $L$. helveticus. The properties of APII-deficient mutants confirmed the presence of APIV.

\section{Cell wall protein composition of APII deficient mutants}

The protein composition of cell wall extracts prepared from parental and mutant strains grown in milk medium (see Methods) was analysed by SDS-PAGE. No signifi-

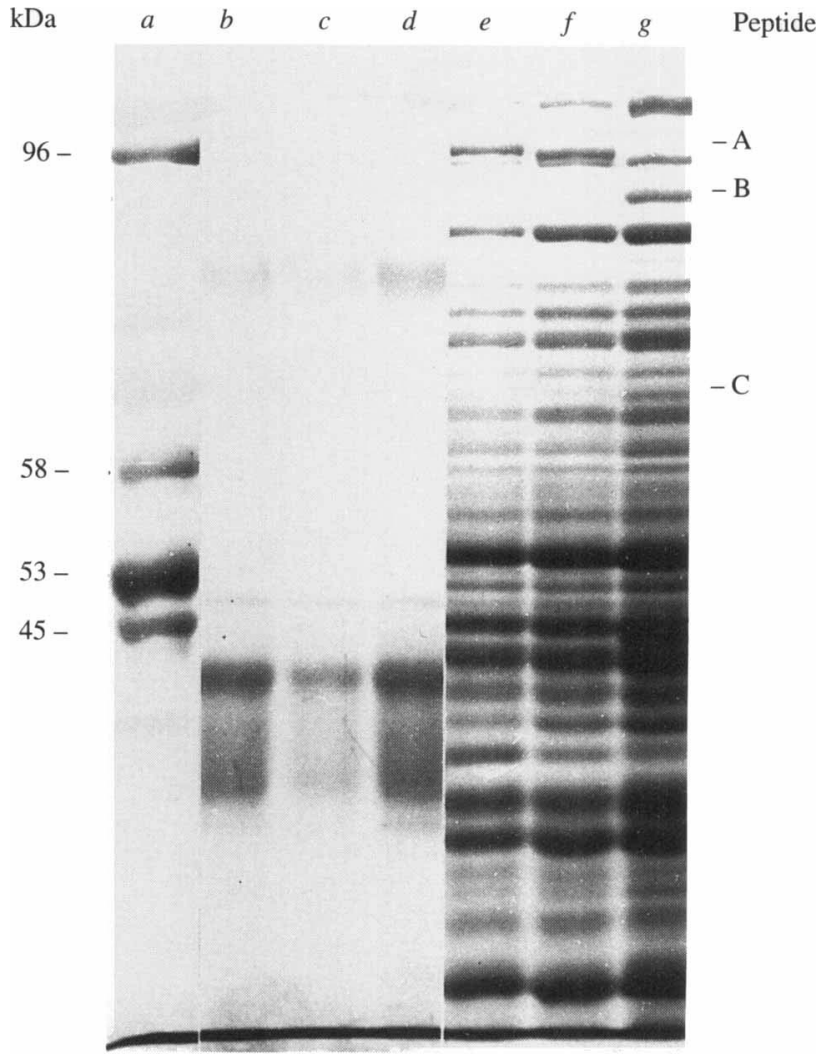

Fig. 2. SDS-PAGE analysis of the proteins released into lysozyme and osmotic fluids from $L$. helveticus parental and AP-deficient strains grown in milk medium. Lane $a$, molecular mass markers: phosphorylase B $(96 \mathrm{kDa})$, catalase $(58 \mathrm{kDa})$, glutamic dehydrogenase $(53 \mathrm{kDa})$, alkaline phosphatase $(45 \mathrm{kDa})$; lanes $b, c, d$, lysozyme fluids from the parental strain and the mutants ITGL2 and ITGL3, respectively; lanes $e, f, g$, osmotic fluids from the parental strain, ITGL2 and ITGL3, respectively. Extract samples loaded on the gel were obtained from $5 \times 10^{8}$ cells.

cant difference was observed between the lysozyme fluids (Fig. 2, lanes $b-d$ ). The protein patterns of osmotic fluids, however, were more complex (Fig. 2, lanes $e-g$ ). Similar electrophoretic protein profiles were displayed by parental and ITGL2 mutant strains, whereas mutant ITGL3

Table 4. Purification of APII from L. helveticus ITGLI

\begin{tabular}{|c|c|c|c|c|c|}
\hline Purification step & $\begin{array}{c}\text { Total activity } \\
\left(\mathrm{mmol} \text { lysyl-pNA } \mathrm{min}^{-1}\right)\end{array}$ & $\begin{array}{l}\text { Total protein } \\
(\mathrm{mg})\end{array}$ & $\begin{array}{c}\text { Specific activity } \\
{[\text { nmol lysyl-pNA (mg }} \\
\left.\text { protein })^{-1} \text { min }^{-1}\right]\end{array}$ & $\begin{array}{c}\text { Yield } \\
\text { (\% activity) }\end{array}$ & $\begin{array}{l}\text { Purification } \\
\text { (-fold) }\end{array}$ \\
\hline Osmotic fluid & $6 \cdot 9$ & 8 & $0 \cdot 86$ & 100 & $1 \cdot 0$ \\
\hline \multicolumn{6}{|l|}{ Anion exchange chromatography } \\
\hline (Mono-Q HR 5/5) & $4 \cdot 4$ & $0 \cdot 41$ & $10 \cdot 5$ & 63 & $12 \cdot 2$ \\
\hline Gel filtration (Superose 12 HR 10/30) & $2 \cdot 4$ & $0 \cdot 12$ & $19 \cdot 7$ & $34 \cdot 5$ & $22 \cdot 8$ \\
\hline \multicolumn{6}{|l|}{ Anion exchange chromatography } \\
\hline (Mono-Q HR 5/5) & 0.73 & 0.03 & $24 \cdot 2$ & $10 \cdot 5$ & $28 \cdot 0$ \\
\hline
\end{tabular}




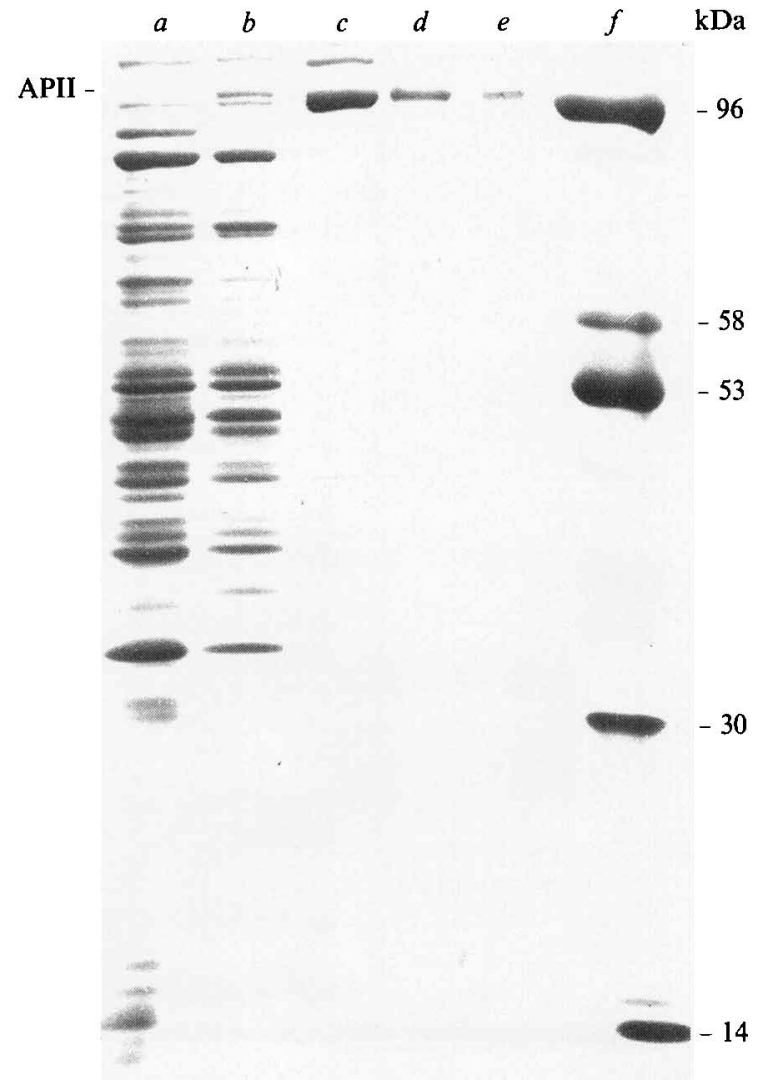

Fig. 3. SDS-PAGE analysis of protein fractions during the purification of APII. Lanes: $a$, ITGL3 osmotic fluid ( $24 \mu \mathrm{g}$ protein); $b, c, d$ and $e$, ITGL1 : $b$, ITGL1 osmotic fluid ( $24 \mu$ g protein); $c$, active pooled fractions after the first MonoQ chromatography (10 $\mathrm{g}$ protein); $d$, active pooled fractions after gel filtration ( $2 \mu \mathrm{g}$ protein); $e$, active pooled fractions after the second MonoQ chromatography $(1.5 \mu \mathrm{g}$ protein); $f$, standards: phosphorylase $\mathrm{B}(96 \mathrm{kDa})$, catalase $(58 \mathrm{kDa})$, glutamic dehydrogenase $(53 \mathrm{kDa})$, carbonic anhydrase $(30 \mathrm{kDa})$ and lysozyme $(14 \mathrm{kDa})$.

was characterized by a total deficiency of peptide A $(96 \mathrm{kDa})$ and an increase in peptides $\mathrm{B}(90 \mathrm{kDa})$ and $\mathrm{C}$ (66 kDa) (Fig. 2, lane $g$ ). Similar results were obtained after cell growth in MRS medium (data not shown).

\section{Purification of APII}

Osmotic fluids prepared from $L$. helveticus ITGL1 cells grown in milk medium were used as enriched extracts for APII purification. The enzyme was purified by three steps of column chromatography as described in Methods. The results of a typical purification are summarized in Table 4. Step 1: During the first anion exchange chromatography, lysyl-pNA-hydrolysing activity eluted at $0.28 \mathrm{M}-\mathrm{NaCl}$. In this fraction, $63 \%$ of total activity, corresponding to $5 \%$ of the total amount of protein, was recovered. Step 2: The concentrated active fraction was applied to a Superose 12 gel filtration column. After elution, the specific activity of the lysylpNA-hydrolysing fraction was increased 1.9-fold. Step 3: The concentrated APII fraction was applied to a MonoQ anion exchange column; after chromatography, the purified enzyme eluted at $0.23 \mathrm{M}-\mathrm{NaCl}$.

By this procedure, the enzyme was purified 28 -fold from osmotic fluid extracts with a yield of $10.5 \%$.

\section{Properties of APII}

The molecular mass of APII was estimated to be $97000 \mathrm{Da}$ by HPLC with a Superose 12 column. SDSPAGE of the purified enzyme fraction resulted in a single protein band corresponding to a molecular mass of $96000 \mathrm{Da}$ (Fig. 3, lane $e$ ). After non-denaturing PAGE, a single red band with the same relative mobility as the purified fraction was observed when enzyme activity was revealed by direct staining on the gel with L-lysyl- $\beta$ naphthylamide (data not shown). The molecular masses of the APs from L. helveticus CNRZ32 and LHE-511 are 97 and $92 \mathrm{kDa}$, respectively (Khalid \& Marth, $1990 b$ : Miyakawa et al., 1992). The protein band for the APII of $L$. helveticus ITGL1 as identified after SDS-PAGE corresponded to polypeptide A, which was absent in the osmotic fluid prepared from mutant ITGL3. This strain may have a nonsense or a deletion mutation altering the APII structural gene or a mutation in a regulatory determinant. In mutant ITGL2, APII was synthesized but inactive; its structural gene might be altered by a missense mutation in an essential site for enzyme activity. The $\mathrm{pI}$ of the enzyme was estimated as 4.8 by IEF (data not shown).

Temperature and $p H$ dependence of $A P I I$. The effect of temperature on APII activity was measured in the range of $5-65^{\circ} \mathrm{C}$. The purified enzyme was equilibrated in $20 \mathrm{~mm}$-MES, pH 6.5 for $5 \mathrm{~min}$ at the appropriate temperature before adding lysyl-pNA. The optimum temperature for enzyme activity was $50^{\circ} \mathrm{C}$. At $55^{\circ} \mathrm{C}$, the enzyme still displayed $50 \%$ of the activity measured at $50^{\circ} \mathrm{C}$. At $60^{\circ} \mathrm{C}$, no hydrolysing activity could be detected. APs from $L$. helveticus CNRZ32 and LHE-511 are most active at $45^{\circ} \mathrm{C}$ and $37^{\circ} \mathrm{C}$, respectively (Khalid \& Marth, $1990 b$; Miyakawa et al. 1992). On the other hand, AP from L. helveticus LHE-511 loses activity at temperatures above $47.5^{\circ} \mathrm{C}$. Therefore, the APII we purified is much more thermotolerant.

The effect of $\mathrm{pH}$ on enzyme activity was examined at $50{ }^{\circ} \mathrm{C}$ in the range of $\mathrm{pH} 4-10$ by using a polybuffer composed of $20 \mathrm{mM}$ each of malic acid, MES, HEPES and boric acid, adjusted to the appropriate $\mathrm{pH}$ values. The optimum $\mathrm{pH}$ for enzyme activity was 6.5 . At $\mathrm{pH}$ values below 5 and above 9, no hydrolysing activity could be detected. The APs from $L$. helveticus CNRZ32 and LHE-511 are most active at $\mathrm{pH} 6.5$ and $7 \cdot 0$, 
Table 5. Relative activity of purified APII on several $p$-nitroanilide derivatives

The rate of hydrolysis of L-lysine-pNA was taken as $100 \%$.

\begin{tabular}{lc}
\hline \hline Substrate & Relative activity (\%) \\
\hline Lys-pNA & 100 \\
Arg-pNA & 29 \\
Leu-pNA & 13 \\
Ala-pNA & 9 \\
Pro-pNA & $<1$ \\
Ala-Pro-pNA & $1 \cdot 6$ \\
Gly-Pro-pNA & $<1$ \\
Val-Ala-pNA & $<1$ \\
\hline
\end{tabular}

Table 6. Substrate specificity of purified APII

\begin{tabular}{lclc}
\hline \hline Substrate & Hydrolysis & \multicolumn{1}{c}{ Substrate } & Hydrolysis \\
\hline Ala-Gly & - & Pro-Ala & - \\
Ala-Pro & - & Pro-Phe & - \\
Ala-Leu & ++ & Pro-Leu & - \\
Ala-Phe & ++ & Pro-Pro & - \\
Ala-His & ++ & Pro-Gly & - \\
Ala-Met & ++ & Pro-Hydroxypro & - \\
Gly-Val & - & Val-Leu & + \\
Gly-Trp & - & Val-Pro & - \\
Gly-Phe & - & Val-Gly & - \\
Gly-Tyr & - & Zgly-Leu & - \\
Gly-Ala & - & NCBZ-Gly-Phe & - \\
Gly-Pro & - & Val-Gly-Gly & - \\
His-Ser & - & Gly-Pro-Ala & - \\
Leu-Pro & - & Leu-Leu-Leu & ++ \\
Leu-Gly & - & Leu-Ala-Pro & ++ in leu and ala-pro \\
Leu-Ala & ++ & Pro-Gly-Gly & - \\
Phe-Pro & - & & \\
Lys-Tyr & - & & \\
\hline \hline
\end{tabular}

++ , Complete hydrolysis.

+ , Slight hydrolysis detectable.

-, No detectable hydrolysis.

respectively. However, they are active under acidic conditions ( $\mathrm{pH} 5.0$ and 4.5 , respectively) (Khalid \& Marth, 1990b; Miyakawa et al., 1992).

Substrate specificity of APII. Table 5 shows the relative rates of hydrolysis for various substrates with $\mathrm{C}$-terminal pNA. The highest activities were found with lysyl-pNA and to a lesser extent with arginyl- and leucylpNA. APs from L. helveticus CNRZ32 and LHE-511 exhibit similar properties (Khalid \& Marth, 1990b; Miyakawa et al., 1992). The kinetic parameters of APII were determined using lysyl-pNA as the substrate. The enzyme hydrolysed lysyl-pNA with a $K_{\mathrm{m}}$ of $0.29 \mathrm{~mm}$ and a $V_{\max }$ of $100 \mathrm{mmol} \mathrm{min}^{-1}(\mathrm{mg} \text { protein) })^{-1}$ (data not shown).

The hydrolytic action of APII towards various peptides was analysed by TLC (Table 6). APII showed a marked preference for di- and tripeptides with Leu or/and Ala. Peptides containing proline or glycine were not hydrolysed. In contrast, AP from $L$. helveticus CNRZ32 hydrolysed the gly-tyr and gly-phe dipeptides (Khalid \& Marth, 1990b). No carboxypeptidase activity was detected with the substrate NCBZ-Gly-Phe.

Effect of various chemical reagents and metal ions on APII activity. Enzyme activity was measured in the presence of different classes of inhibitors or metal ions to obtain some information about the active site of APII. Inhibitors of metalloenzymes such as EDTA ( $0.1 \mathrm{mM})$ and 1,10-phenanthroline (1 $\mathrm{mM})$, totally inhibited the purified enzyme. On the other hand, inhibitors of serine enzymes (PMSF), compounds acting on the SH groups of proteins [monoiodoacetic acid $1 \mathrm{~mm}$, E64 $(N-[N-(\mathrm{L}-3$ transcarboxyoxirane - 2 - carbonyl) - $\mathrm{L}$ - leucyl) - agmatine; Boehringer-Mannheim) $1 \mathrm{~mm}$ ] and reducing agents (dithiothreitol, $1 \mathrm{mM}, \beta$-mercaptoethanol, $1 \mathrm{~mm}$ ) had no effect on APII activity. These results suggested that intact disulphide or thiol groups are not essential for enzyme activity. In contrast, AP from $L$. helveticus CNRZ32 is inhibited by thiol-blocking reagents such as $p$-chloromercuribenzoate, $N$-ethylmaleimide, iodoacetate and iodoacetamide, indicating that thiol groups are essential for this enzyme.

The activity of EDTA-treated APII was totally recovered by the addition of $1 \mathrm{mM}-\mathrm{CoCl}_{2}$, but only $44 \%$ or $26 \%$, respectively, was restored by the addition $1 \mathrm{mM}$ $\mathrm{CaCl}_{2}$ or $1 \mathrm{~mm}-\mathrm{MnCl}_{2}$. Addition of $1 \mathrm{~mm}-\mathrm{CoCl}_{2}$ restored $35 \%$ of the activity of 1,10-phenanthroline-treated APII. The enzyme was totally inhibited by $1 \mathrm{mM}-\mathrm{ZnCl}_{2}$ or $1 \mathrm{~mm}-\mathrm{CuCl}_{2}$, and partially inhibited by $\mathrm{MnCl}_{2}$ at $0.1 \mathrm{mM}$ $(54 \%)$ or $1 \mathrm{~mm}(90 \%)$ or $\mathrm{CoCl}_{2}$ at $1 \mathrm{~mm}(17 \%)$ or $10 \mathrm{mM}$ ( $73 \%$ ). High concentrations (10 $\mathrm{mM}$ ) of $\mathrm{CaCl}_{2}$ and $\mathrm{MgCl}_{2}$ had no effect on enzyme activity. AP activities from $L$. helveticus CNRZ32 and LHE-511 are strongly activated by $\mathrm{Co}^{2+}(1 \mathrm{mM})$ and partially inhibited $(10 \%$ and $30 \%$, respectively) by $\mathrm{Zn}^{2+}(1 \mathrm{mM})$ (Khalid \& Marth, $1990 b$; Miyakawa et al. 1992).

\section{Conclusions}

The development of a differential extraction procedure for cell envelope proteins of $L$. helveticus allowed us to show that two components of the proteolytic system, APII and APIV, were localized in the cell wall. We have shown that these enzymes displayed different properties: APII is a metallo-enzyme with a broad substrate specificity, and is the only AP from $L$. helveticus able to hydrolyse lysyl-pNA, whereas APIV is responsible for a part of the leucyl-AP activity but is not a metalloenzyme.

APII showed similar properties (molecular mass, optimum $\mathrm{pH}$ ) with $L$. helveticus $\mathrm{CNRZ32}$ and $L$. helveticus LHE-511 APs, but had no essential SH group, 
unlike AP from strain CNRZ32. Moreover, compared to the LHE-511 AP, APII had a much higher optimal temperature.

The broad substrate specificity, cell wall location and several other properties of the purified enzyme suggest that APII from L. helveticus ITGL1 contributes to the degradation of casein. APII-deficient mutants (ITGL2 and ITGL3) have been used for Emmental cheese production, which resulted in flavour defects (Prost \& Chamba, 1990). The bitter flavour which results from protein degradation is apparently caused by an accumulation of bitter peptides containing a high proportion of hydrophobic amino acids. The APII of L. helveticus ITGL1 might contribute to the development of cheese flavour by processing bitter peptides. Research is now in progress to purify APIV from osmotic fluids of ITGL3 mutant strain, devoid of APII.

We are grateful to Bernard Dequatre for excellent technical assistance. We thank the Institut Technique du Gruyère for providing aminopeptidase-deficient strains. This work was supported by grants from the Centre National de la Recherche Scientifique (UMR 106) and the Université Claude Bernard.

\section{References}

Atlan, D., Laloi, P. \& Portalier, R. (1989). Isolation and characterization of aminopeptidase-deficient Lactobacillus bulgaricus mutants. Applied Environmental Microbiology 55, 1717-1723.

Atlan, D., Laloi, P. \& Portalier, R. (1990). X-prolyl-dipeptidyl aminopeptidase of Lactobacillus delbrueckii subsp. bulgaricus: characterization of the enzyme and isolation of deficient mutants. Applied Environmental Microbiology 56, 2174-2179.

BarTels, H. J., Johnson, M. E. \& Olson, N. F. (1987). Accelerated ripening of Gouda cheese. II. Effect of freeze-shocked Lactobacillus helveticus on proteolysis and flavor development. Milchwissenschaft 42, 139-144.

BRADFORD, M. M. (1976). A rapid and sensitive method for the quantification of microgram quantities of protein utilizing the principle of protein-dye binding. Analytical Biochemistry 72, 248-254.

De Man, J. C., Rogosa, M. \& Sharpe, E. (1960). A medium for the cultivation of lactobacilli. Journal of Applied Bacteriology 23, $130-135$.

Ezzat, N., El Soda, M., Desmazeaud, M. \& Ismail, A. (1986). Peptide hydrolases from thermobacterium group of lactobacilli. III. Characterization of the intracellular exopeptidases. Le Lait 66, 445-451.

Hickey, M. W., Hillier, A. J. \& JAGo, G. R. (1983). Peptidase activities in lactobacilli. Australian Journal of Dairy Technology 38, $118-123$.

Khalid, N. M. \& Marth, E. H. (1990a). Purification and partial characterization of a prolyl-dipeptidyl aminopeptidase from Lactobacillus helveticus CNRZ 32. Applied Environmental Microbiology 55, 381-388.

Khalid, N. M. \& Marth, E. H. (1990b). Partial purification and characterization of an aminopeptidase from Lactobacillus helveticus CNRZ 32. Systematic and Applied Microbiology 13, 311-319.

KoK, J. (1990). Genetics of the proteolytic system of lactic acid bacteria. FEMS Microbiology Reviews 87, 15-42.

KoK, J. \& Venema, G. (1988). Genetics of proteinases of lactic acid bacteria. Biochimie 70, 475-488.

LaAN, H., Smid, E. J., TAN, P. S. T. \& Konings, W. N. (1989). Enzymes involved in the degradation and utilization of casein in Lactococcus lactis. Netherland Milk Dairy Journal 43, 327-345.

LAEMmLI, U. (1970). Cleavage of structural proteins during the assembly of the head of bacteriophage T4. Nature, London 227, 680-685.

Laloi, P., Atlan, D., Blanc, B, Gilbert, C. \& Portalier, R. (1991). Cell-wall-associated proteinase of Lactobacillus delbrueckii subsp. bulgaricus CNRZ 397: differential extraction, purification and properties of the enzyme. Applied Microbiology and Biotechnology 36, 196-204.

LaW, B. A. \& Koshlstad, J. (1983). Proteolytic system in lactic acid bacteria. Antonie van Leeuwenhoek 49, 225-245.

MiLLER, J. (1972). Experiments in Molecular Genetics. Cold Spring Harbor, NY: Cold Spring Harbor Laboratory.

Miyakawa, H., Kobayashi, S., Shimamura, S. \& Tomita, M. (1992). Purification and characterization of an aminopeptidase from Lactobacillus helveticus LHE-511. Journal of Dairy Sciences 75, 27-35.

Monnet, V., Le Bars, D. \& Gripon, J. C. (1986). Specificity of a cell wall proteinase from Streptococcus lactis NCDO 763 towards bovine $\beta$-casein. FEMS Microbiology Letters 36, 127-131.

Monnet, V., Bockelman, W., Gripon, J. C. \& Teuber, M. (1989). Comparison of cell wall bound proteinases from Lactococcus lactis subsp. cremoris ACI and Lactococcus lactis subsp. lactis NCDO 763 II. Specificity towards bovine $\beta$-casein. Applied Microbiology and Biotechnology 31, 112-118.

Prost, F. \& Chamba, J. F. (1990). Rôle de l'activité aminopeptidasique des lactobacilles thermophiles de l'Emmental. Réunion du Club des Bactéries Lactiques. Jouy en Josas, France.

Thomas, T. D. \& Pritchard, G. G. (1987). Proteolytic enzymes of dairy starter cultures. FEMS Microbiology Reviews 46, 245-268. 